\title{
リゾチームの生理効果に関する研究 (1)
}

\author{
Studies on the Physiological Action of Lysozyme (1)
}

\author{
動物に対するリゾチーム投与試験 \\ Effects of lysozyme administration on animals
}

(昭 和 42 年 2 月 20 日受 理)

\begin{abstract}
祐川金次郎菊池俊彦繁田晴 美 (Kinziro Sukegawa) (Toshihiko Kikuchi) (Harumi Handa)
\end{abstract}

The physiological effect of lysozyme was examined. Lysozyme does not catalyze casein decomposition in vitro. On feeding rabbits and rats with the trial infant formula, containing $130 \mathrm{mg}$ percent of lysozyme (Px), the following results were observed.

1) Lysozyme content in human milk was determined as $3-10 \mathrm{mg}$ percent. Cow's milk contains only $0.03-0.17 \mathrm{mg}$ percent. Lysazyme content of cow's milk is about $1 / 100$ of human milk.

2) Lysozyme content in blood serum and feces, especially in feces, was increased when fed rabbits with the Px.

3) Nitrogen distributions in feces of rabbits were determined by the use of Dowex- $50 \mathrm{~W}$ ion exchange resin. Low molecular weight $\mathrm{N}$-compounds in feces were increased by infant formula, Snow Brand Neomilk PF (PF), feeding compared with Oriental diet feeding. No significant difference in $\mathrm{N}$-distribution in feces was observed between $\mathrm{Px}$ and $\mathrm{PF}$ feedings.

4) On feeding rats with either $\mathrm{Px}$ or $\mathrm{PF}$, the $\mathrm{pH}$ of feces was decreased and the count of Lactobacillus bifidus was increased. This tendency was especially remarkable with the Px feeding. Changing the feed to Oriental diet, $\mathrm{pH}$ of feces was again increased and the count of Lactobacillus bifidus was decreased.

1922年 Flaming によって発見命名されたリり゙チーム は，溶菌性䣼蜏として，近年は多数の研究対象となって きた。すなわち，その性質を明らかにすること，体液中 の分布, 化学的性質および薬理的効果, その作用機構, 生理的拈よび病理的条件に上る変化, 医薬効果, 生理活 性に関しての研究が行なわれている。その結果, この醉 素は, 抗菌作用, 抗ウイルス作用, 広義の免疫作用, 血 液凝固作用拉よび止血作用, 消炎作用, 牛乳の消化作用 などのあることが認められ，とくに小児科領域において は,リソ゚チームの臨床的応用は非常に興味ある成績を与 えている。すなわち, 新生児および生後 1 力月以内の乳 児で抗菌および抗ウイルス性の先天的な防禦機跷に対し て，母体から5けついできた抗体とともに良好な影響を 与えている。

リゾチームは白色, 無臭の甘味をすつ結晶性の粉末 で1)，分子量は約 $15,000 ， 129$ 個のアミノ酸が鎖状に結 合した塩基性 タンパク質で，その棈造も決定されてい
る2)。自然界には卵白をはじめとして，ヒトや動物の涙 液, 唾夜, 血夜, 乳汁などの体液や各臟器のほか, 植物, 細菌などに広く分布している。しかし牛乳にはほとんど 存在しな(3)4)。

リゾチームがとくに注目される性質は䣼素作用をすつ ことで,グラム陽性菌の菌壁を構成しているムコポリサ ッカライドに作用して, 低分子量の窒素を含んだ糖類に 分解することであるる。このムコポリサッカライドが分 解されてできた含窒素糖類がビフィダス菌の增殖因子で あることも知られている゙。このような醉素作用をるち ながら動物の体内て酵素によって分解されずに，体液や 重要な腀器に存在していることはなんらかの生理的意義 をもっていることが予想される。最近では乳睍栄養とく に人工栄養児に拁けるリジチームの効果についての報告 あいくつか発表されている7) 10)。

母乳栄美児の腸内には㒖気性乳酸菌のビフィダス菌が 压倒的に多く，また萁便中にす多量のリゾチームが存在 
しているが，人工栄養児の腸内には大腸菌が圧到的に多 く、リジチームも母乳栄養児に比校しては極めて少な (18) 11)。母乳栄養児では母乳中のリジチームが分解さ れずに腸まで達しているこど1，また隀液中晹内にりり チームが存在していることは，有害細菌やウイルスの程 口的侵入に対して，その增殖を防ぐ效果があると考えら れている(⿻11)。

著者らは，上述の上5な生理作用をすち，しかも人乳 中に極めて多く含有され，牛乳中にははとんど含まれて いないことが，母乳栄盖児と人工栄養児の発有上，とく に病気に対する抵抗性の閭題と関連があるのではないか と考え，人工栄養児にリゾチームを利用すべく，まず家 鬼およびネズミにリジチーム添加粉乳を投与してその効 果を検討した。

\section{実 験 方 法}

\section{1. 実験対象}

\section{a. 飼 料}

1) 固型飼料：家鬼掞よびネズミの固型飼料として は，オリエンタルの家象およびネズミ用を自由に摂取さ せた。

2) 対照粉乳: 雪印ネオミルク PF（以下 PF と略 す）を, 家鬼の場合には $30 \%$ 溶液として $2 \sim 4$ 回/日, 1 回 20〜 $50 \mathrm{ml}$ をカテーテルを用いて胃内に投入した。 ネズミの場合には水で練って自由に摄取させた。

3) 試験粉乳：雪印ネオミルクPFKリゾチームを $130 \mathrm{mg} / 100 \mathrm{~g}$ 添加したものである（以下 Px と略す）。 上記同様に投与した。

なお，家鬼は生後 2 カ月および 1 年のものであり，ネ ズミは生後 20 日のものを用いた。

\section{b. 実験期間}

家象に対しては，それぞれの試料を 7 〜 10日間投与後 採血，採便して実験に用いた。

ネズミの場合には，9匹を 3 群に分け，各飼料を各群 に交互に 1 週間ずつ投与， $6 〜 7$ 日目に採便して各群の 3 匹分を混合，菌鋠の湖定を行なった。

飼料の種類怙よび投与方法（各 1 週間投与）

\begin{tabular}{|c|c|c|c|c|}
\hline A 群 & $\begin{array}{l}\text { オリエン } \\
\text { タル }\end{array}$ & $\mathrm{Px}$ & PF & オリエンタル \\
\hline B群 & $P x$ & PF & $\begin{array}{l}\text { オリエン } \\
タ ル ~\end{array}$ & オリエンタル \\
\hline C 群 & PF & $\begin{array}{l}\text { オリエン } \\
\text { タル }\end{array}$ & $\mathrm{Px}$ & オリエンタル \\
\hline
\end{tabular}

2. 測定方法

a 、リゾチーム

人乳，牛乳，血清および蕒便中のリゾチーム含量は， リゾチーム活性標準曲線から求めた（因 1 )。
因 1. Lysozyme 濃度の標準曲線

M. Lysodeikticus $150 \mathrm{mg} / 100 \mathrm{ml}, \mathrm{M} / 15$ phosphate buffer $\mathrm{pH} 6.24,37^{\circ} \mathrm{C}, 20 \mathrm{~min}$. 反応

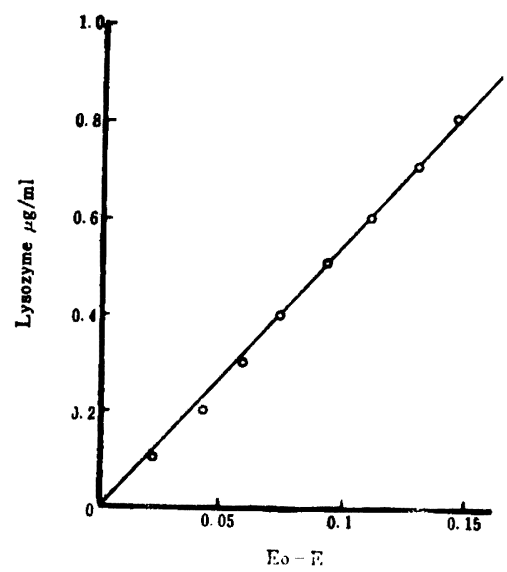

1）リゾチーム活性標準曲線

精慗リゾチーム（エーザイ社）を $0.1 〜 1.0 \mu \mathrm{g} / \mathrm{ml}$ に なるよ5に Sörensen buffer $\left(\mathrm{M} / 15 \mathrm{KH}_{2} \mathrm{PO}_{4} 4.3: 1\right.$ $\mathrm{M} / 15 \mathrm{Na}_{2} \mathrm{HPO}_{4}, \mathrm{pH} 6.24$ ) に溶解した。

基質液としては M. Lysodeikticus ${ }^{12}$ ) を約 $150 \mathrm{mg} /$ $100 \mathrm{ml}$ Sörensen buffer に㥎濁させ, Coleman spectrophotometer $540 \mathrm{~m} \mu$ で透過事が約 $10 \%$ になるよ 5 に buffer を加えて調整する。

リゾチーム活性曲線の作成は, 各濃度のリゾチーム溶 液 $3 \mathrm{ml}$ を試験管に採り, $37^{\circ} \mathrm{C}$ 温浴中で加温, これに $37^{\circ} \mathrm{C}$ に保持した $M$. Lysodeikticus 緐濁液 $3 \mathrm{ml}$ を加兄 $\tau, 20$ 分間反応後, Coleman spectrophotometer 540 $\mathrm{m} \mu$ で蒸留水に対して $\mathrm{E}$ を測定。同様の操作で buffer とM. Lysodeikticus 顛濁液を各 $3 \mathrm{ml}$ 混合したものに ついてブランク試験を行ない $\mathrm{E}_{0}$ を求めた。得られた $\mathrm{E}_{0}$ ，Eからリゾチーム活性曲線を作成した。リゾチーム 濃度0.1 0.8 $\mu \mathrm{g} / \mathrm{ml}$ の籁围では $\mathrm{E}_{0}-\mathrm{E}$ と直線関係が得 られる。

2) 乳汁, 血清, 翼便中のリゾチーム

人乳中のリゾチーム含量は,つぎのようにして測定し $た^{(4) 18)}$ 。

人乳

$0.5 \% \mathrm{NaCl}$ 溶液を等量混合

$\mathrm{pH} 4.6,1$ 時間放置，2,000 rpm.10分間

沪過, 東洋沪紙 No. 5B 除タンパク

$1 \mathrm{ml}$ に $0.5 \% \mathrm{NaCl}$ 溶液を加えて $100 \mathrm{ml}$ とする

また牛乳中のリジチーム含量については，

牛乳 $5 \mathrm{ml}+5 \mathrm{ml} 0.5 \% \mathrm{NaCl}$

2,000 rpm. 10 分間, 脂肪分離除去 
$\mathrm{pH} 4.6,37^{\circ} \mathrm{C} 10$ 分間保持

$\downarrow$

2, $000 \mathrm{rpm} .10$ 分間，除タンパク

沪過 東洋沪紙 No. $5 B$

上記のようにして得られた沪液を $0.5 \% \mathrm{NaCl}$ 溶液で 適度に希积し，その $3 \mathrm{ml}$ を測定に用いた。

血清の場合には，血清 $0.1 \mathrm{ml}$ を $0.5 \% \mathrm{NaCl}$ 溶液で $10 \mathrm{ml}$ に希釈してその $3 \mathrm{ml}$ を用いた。

また鿓便中のリゾチーム含量は, 試料 $2 \sim 5 \mathrm{~g}$ を 0.5 $\% \mathrm{NaCl} 100 \mathrm{ml}$ に覩濁させ, $\mathrm{pH} 4.6$ にして除タンパ クした沪液を使用した。

以上のよ 5 に調製した試料 $3 \mathrm{ml}$ と $M$. Lysodeikticus 愁濁液 $3 \mathrm{ml}$ を $37^{\circ} \mathrm{C}, 20$ 分間反応させて, 蒸留水に対し て $\mathrm{E}$ 値を测定。同様に試料と基質液各 $3 \mathrm{ml}$ を混合して 直ちに $\mathrm{E}_{0}$ を求め, $\mathrm{E}_{0}-\mathrm{E}$ からリゾチーム含量を活性標 準曲線から求めた。

3) M. Lysodeikticus の調製 ${ }^{12)}$

M. Lysodeikticus（ATCC 4698）を保存培地に接種後 $37^{\circ} \mathrm{C}, 24$ 時間培養する。培盖した菌株は氷室に保存し 2 週間ごとに新規の保存培地に移植し培荃した。

保存培地 (Waksman Collection No.19培地)

\begin{tabular}{|c|c|c|}
\hline \multicolumn{2}{|c|}{ ペプトン } & $0.5 \%$ \\
\hline \multicolumn{2}{|c|}{ 塩化ナトリウム } & 0.5 \\
\hline \multicolumn{2}{|c|}{ 酵母エキス } & 0.1 \\
\hline 寒 & 天 & 2.0 \\
\hline 蒸 留 & 水 & 適量 \\
\hline 全 & 量 & $100 \%$ \\
\hline
\end{tabular}

$\mathrm{NaOH}$ 液を用いて pH 7.2 に調整し隇菌する。

培地 $50 \mathrm{ml}$ に保存培養菌種を接種し, $30^{\circ} \mathrm{C}, 48$ 時間 振逿培養する。得られた前培盖液を隇菌培地 $100 \mathrm{ml}$ 入れたエルレンマイヤーフラスコに $2 \%$ 量接種し， $30^{\circ}$ C，72時間振盪培養する。培羕終了後, 全菌体を遠心分 離 $\left(0^{\circ} \mathrm{C}, 5,000 \mathrm{rpm} .5\right.$ 分間), 分離菌体を䄪 $100 \mathrm{ml}$ の蒸留水で 3 回洗浄遠心分離した。得られた菌体に的 $8 \mathrm{ml}$ の蒸留水を加え, よく摜拌して均一な眊濁液を作 りこれにフセトン約 $80 \mathrm{ml}$ をよく覧拌しながら滴下し て遠心分離する $\left(0^{\circ} \mathrm{C}, 3,000 \mathrm{rpm} .10\right.$ 分間)。上澄液は すて，菌体に䄪 $8 \mathrm{ml}$ のアセトンを加えて筧捧してから さらにアセトン約 $80 \mathrm{ml}$ を擋䢁しながら滴下する。遠心 分離後，上登液を除く。この操作を 2 回くりかえした。 最後にアセトン菌体は凍結真空乾嬠した。

菌体捕集培地組成

$\begin{array}{ll}\text { ペプトン } & 0.5 \% \\ \text { 塩化ナトリウム } & 0.5 \\ \text { 肉エキス } & 0.3 \\ \text { 醉母ェキス } & 0.1\end{array}$

\begin{tabular}{ll} 
蒸留水 & 適量 \\
\hline 全 量 & $100 \%$
\end{tabular}

$\mathrm{NaOH}$ 液を用いて $\mathrm{pH} 7.2$ に調整する。

b. 冀便中の窒素化合物の分布 ${ }^{13) 14}$

粪便20 $\mathrm{g}$ 前後に蒸留水を加えてホモブレンダーでよく 混和して $100 \mathrm{ml}$ とし, 沪紙 No. 2 で汇過。汇液 10〜20 $\mathrm{ml}$ を Dowex-50W, X-16, 12, 8, 4, 2 の各カラム $(0.9 \times 18 \mathrm{~cm})$ に流速 $0.5 \mathrm{ml} /$ 分 の条件で流下，水洗液 の流速も $0.5 \mathrm{ml} /$ 分とし, 試料扣よび洗液を約 $80 \mathrm{ml}$ 回 収,これを $100 \mathrm{ml}$ にメスアップした。流出液中の率素 を定量して未吸着の窒素量を求め, これから各カラムに 対する吸着窒素量を算出し, 算便中の $\mathrm{N}$ - 化合物の分布 を测定した。

c . 蕒便中の細菌数および菌㒈

無菌的に 0.5〜1.0 g の試料を採取し, $4.5 \sim 9 \mathrm{ml}$ の隇 菌生理食塩水を加えて隇菌した乳鉢中で磨砾し，10倍希 釈液とし, 順次希釈して使用した。

\section{1 ）好気性生菌数}

肝臓培地を用い, 常法により平板とし， $37^{\circ} \mathrm{C}, 24$ 時 間培養後，発生した全集落を測定した。

\section{2) 濑気性生菌数}

肝臓培地平板に希釈夜 $0.1 \mathrm{ml}$ をコンラージ棒で塗抹, 黄リン然焼法による嫌気状態で $37^{\circ} \mathrm{C}, 72$ 時間培盖し, 発生した全集落を測定した。

3) ビフィダス菌数

根岸培地平板を用い，濑気性生菌数と同様の方法で培 養し，発生した白色光沢を有する集落数を測定した。ま ぎらわしい集落については染色, 検鏡を行ない, その形 態を観察してのち測定した。

4 ) 大腸菌群数

デオキシコレート培地（栄研）を用い，常法によって 平板とし, $37^{\circ} \mathrm{C}, 24$ 時間培養, 発生した赤色集落を測 定した。

d. $\mathrm{pH}$ の測定

少量の試料を採取し，これに 9 倍量の隇菌生理食塩水 を加えて乳鉢で磨确， $\mathrm{pH}$ 試験紙で測定した。

\section{結果および考察}

\section{1. 乳汁中のリゾチーム含量}

ヒトおよびその他の動物の乳汁中のリゾチーム含量に ついては, 諸外国での測定結果が多〈報告されている 15)。著者らは日本人人乳扰よび牛乳について, 少数例で はあるが測定した結果は表 1 のようであった。

人乳についての諸外国の報告值は，個体差がきわめて 大きく, 常乳 3 $300 \mathrm{mg} / 100 \mathrm{ml}$, 初乳 $9 \sim 102 \mathrm{mg} / 100 \mathrm{ml}$ でそ平均值はそれぞれ $39 \mathrm{mg}, 46 \mathrm{mg} / 100 \mathrm{ml}$ であ 
表 1. 人乳および牛乳中のリゾチーム含量

\begin{tabular}{|c|c|c|c|c|}
\hline 人 & 乳 & $\mathrm{g} / 100 \mathrm{ml}$ & 牛 乳 & $\mathrm{mg} / 100 \mathrm{ml}$ \\
\hline 分婏後 & 0 日 & 10.73 & & 0.062 \\
\hline$\prime \prime$ & 8 & 3.91 & & 0.130 \\
\hline$\prime \prime$ & 14 & 6.35 & & 0.135 \\
\hline$\prime \prime$ & 15 & 3.41 & & 0.062 \\
\hline$\prime \prime$ & 23 & 11.35 & & 0.112 \\
\hline$\prime \prime$ & 30 & 10.77 & & 0.070 \\
\hline$\prime \prime$ & 43 & 1.43 & & 0.172 \\
\hline$\prime \prime$ & 70 & 4.52 & & 0.087 \\
\hline$\prime \prime$ & 73 & 8.63 & & 0.035 \\
\hline$\prime \prime$ & 96 & 5.12 & & 0.062 \\
\hline
\end{tabular}

る315)。これらの值と比較した場合には, 著者らの結果は 一般に低かった。

一方牛乳については, 人乳に比較してきわめて少ない と報告されている33)。われわれの結果です，0.035〜 $0.172 \mathrm{mg} / 100 \mathrm{ml}$, 人乳の約 $1 / 100$ 以下であった。

2. 血清拈よび冀便中のリゾチーム含量

家鬼血清中のリジチーム濃度は, 図 2 に示したよ5に 固型飼料投与時では, 12例の測定結果は䄪 $1 \mathrm{mg} / 100 \mathrm{ml}$ であった。これらの家鬼に PF を与えた場合には，5 例 中 2 例に若干の増加が認められた。な抢用いた PF には M. Lysodeikticus を溶菌する物質が $1 \sim 7 \mathrm{mg} / 100 \mathrm{~g}$ 程 度含有されていた。この物質が果してりゾチームか否か は不明である。一方, リゾチームを添加した 試 験 粉乳 （Px）を投与した家鬼では，増加の割合はそれぞれ異な っていたが, 全例とも增加した。

また翼便中のリゾチーム含量については図 3 に示した が，Px 投与によって増加していることが認められる。

ヒトの場合には, 少量ではあるが早産児や新生児の涙 液中にリ・チームが含有され, 月がたつにつれて, その 授孚の種類には無関係に増大するが，早産児の唾液中に

図2，Lysozyme 添加粉乳 $(\mathrm{Px})$ 扰よび PF 投与 による家來血清中の Lysozyme 含量の変動 （ 7 〜 10日間投与）

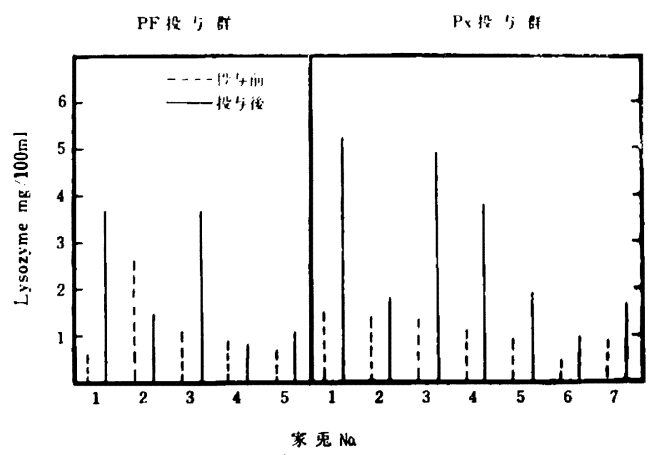

図3．Px 扰よび PF 投与による家樃 蕒便中の Lysozyme 含量の変動 （ 7 〜 10日間投与）

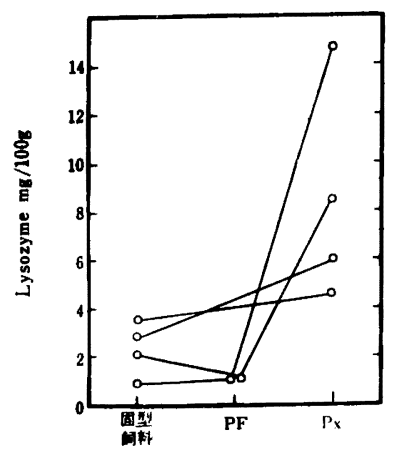

はほとんど含まれない。しかし授乳によって增大し，と くに母乳の授乳によって著明に增加することも知られて いる。一方，血清中のリゾチーム值は，年令によって大 羑がなく, 毎日生理的な変化を示すが, 乳児の方が一般 に高く，とくに母乳栄養児の方が高値を示すという。こ れは技そらく人乳中にリゾチームが多量に存在するため であると考えられている。

3. 蕉便中の窒素化合物の分布

Dowex-50W H型樹脂によって, 固型飼料, PF およ び Px 投与家鬼鿓便中の $\mathrm{N}$-分布の篩分別を行なった結 果を図 4 に示した。

Dowex-50 樹脂に吸着される $\mathrm{N}-$ 化合物の形態は, Dowex-50W を形成する ジビニールヘンンゼン (DVB) の含量によって異なり，つぎのよ5に $\mathrm{N}$ - 化合物の笠分 別ができる ${ }^{13) 14 。}$

DVB $16 \%$ : アミノ酸, 低分子 N-化合物

$$
\begin{aligned}
12 & : \text { オリゴペプチド } \\
8 & : \text { オリコ゚ペプチド } \\
4 & : \text { ペプトン, その他のペプチド } \\
2 & : \text { プロテオース }
\end{aligned}
$$

家鬼糞便中の $\mathrm{N}$ - 化合物の分布については, 家鬼に固 形飼料を投与した場合には，アミノ酸および低分子 N化合物含量が少なく，樹脂に吸着されない上うな高分子 の非タンパク態 $\mathrm{N}$ - 化合物およびタンパク態の $\mathrm{N}-$ 化合 物が多く排泄されている。一方 PF 投与の場合には，鿓 便中にはタンパク態 $\mathrm{N}$ - 化合物の排泄は全くなく, 非タ ンパク態 $\mathrm{N}$ - 化合物の排泄が若干ある程度で，その他は すべて低分子 $\mathrm{N}$-化合物であった。さらにリッ゙チームを 添加した試験粉乳（Px）投与に拈いては，PF 投与の場 合と大体同様の傾向を示す $\mathrm{N}$ - 化合物の分布状態であっ た。

リゾチームは㘠5に示したように，in vitroにおいて はカゼインに対しては直接分解作用を示さないし，また 
图 4．Px 扎よび PF 投与家鬼蓝便中の $\mathrm{N}$-化合物の分布 (Dowex-50W による分割)
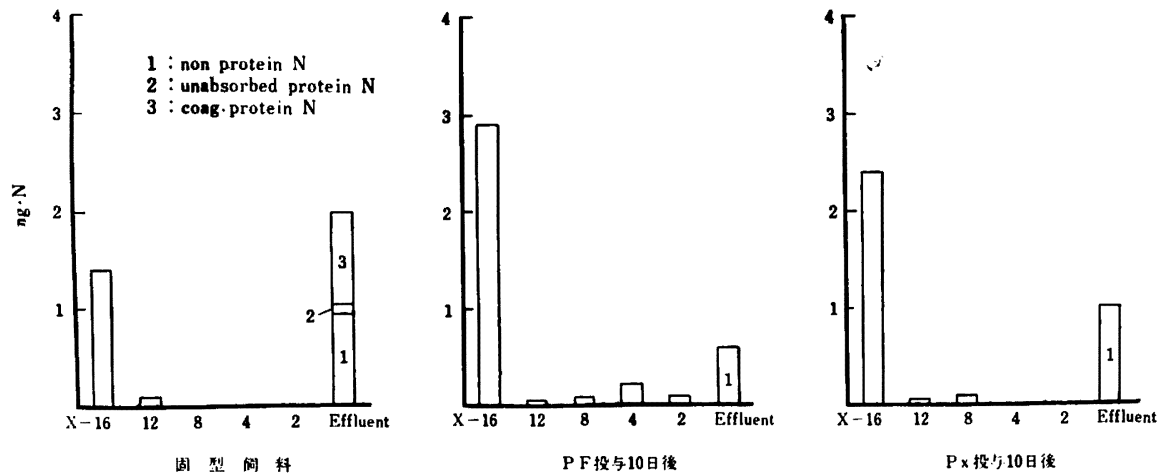

図 5. Lysozyme の casein 分解力 (Dowex-50W に上る $\mathrm{N}-$ 化合物の分布)

Casein solution 1\%, Lysozyme, Trypsin は Casein の 1/100 濃度 $\mathrm{M} / 15$ phosphate buffer, $\mathrm{pH} 6.2,38^{\circ} \mathrm{C} 6 \mathrm{hrs}$. 反応



あらかじめリッ゙チームを作用させた後 トリプシンで分解した場合にも，トリ プシン単独に作用させたときとその分 解産物にはほとんど差が認められない ので, in vitroにおけるカゼイン分 解の酵素作用はまったくないすのと考 えられる。しかし, in vivo におい ては,リゾチームの物理化学的特性が 乳汁タンパク質に対して, 消化吸収機 構に関連した作用を示す多くの実験事 実がある。例えば牛乳タンパク質に作 用して知紐な凝固物を形成させるため に，消化，吸収がよくなることも考え られているが，ヒトと家鬼では消化機 楧す鲑なるので，かならずしす好結果 が得られるとはかぎらない。

\section{4. 腸内菌芠の变動}

ネズミに対して，固形飼料， 。PF お よび Pxをそれぞれ 1 週間間隔に投与
こ・図6.投与飼料によるネズミ萁便中の $\mathrm{pH}$ および菌叢の変動
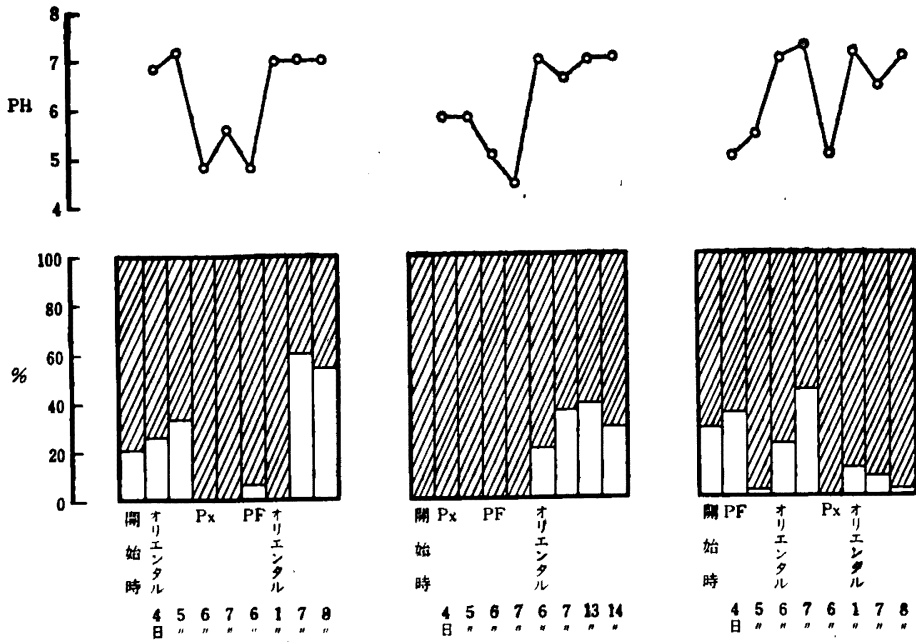

45679671314

B $7 n-1$

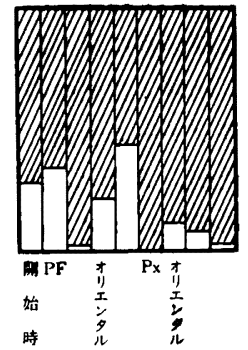



cru- 7 


\section{栄養と食粗}

表 2. 投与飼料によるネズミ蕒便中の $\mathrm{pH}$ および菌叢の変動

\begin{tabular}{|c|c|c|c|c|c|c|c|c|}
\hline \multicolumn{2}{|c|}{ 投与飼料の種類 } & $\mathrm{pH}$ & 好気性菌 & $\begin{array}{c}\text { 婔気性菌 } \\
/ \mathrm{g} \quad \mathrm{A}\end{array}$ & ビフ $1 \mathrm{~g}$ ダス菌 & $\begin{array}{cc}大 \text { 腸菌群 } \\
/ \mathrm{g} & \mathrm{C} \\
\end{array}$ & $\begin{array}{l}\mathrm{B} / \mathrm{A} \\
\times 100\end{array}$ & $\begin{array}{l}\mathrm{C} / \mathrm{A} \\
\times 100\end{array}$ \\
\hline \multicolumn{2}{|l|}{ グループ A } & & $\infty$ & $3.3 \times 10^{9}$ & $2.6 \times 10^{\circ}$ & $1.5 \times 10^{5}$ & 79 & 0 \\
\hline \multirow{2}{*}{$\begin{array}{l}\text { 実験開始時 } \\
\text { オリエンタル }\end{array}$} & 4 日後 & 6.8 & $\infty$ & $3.8 \times 10^{9}$ & $2.8 \times 10^{\circ}$ & $6.2 \times 10^{5}$ & 74 & 0 \\
\hline & $5 / 1$ & 7.2 & $1.1 \times 10^{10}$ & $2.7 \times 10^{9}$ & $1.8 \times 10^{9}$ & $1.6 \times 10^{6}$ & 67 & 0 \\
\hline \multirow[t]{2}{*}{$\mathrm{Px}$} & $6 \prime \prime$ & 4.8 & $2.6 \times 10^{10}$ & $1.5 \times 10^{10}$ & $1.6 \times 10^{10}$ & $1.0 \times 10^{4}$ 以下 & 100 & 0 \\
\hline & $7 \prime \prime$ & 5.6 & $9.2 \times 10^{9}$ & $1.6 \times 10^{10}$ & $2.3 \times 10^{10}$ & $4.7 \times 10^{5}$ & 100 & 0 \\
\hline PF & $6 \prime \prime$ & 4.8 & $1.9 \times 10^{10}$ & $1.7 \times 10^{10}$ & $1.6 \times 10^{11}$ & $2.0 \times 10^{4}$ 以下 & 94 & 0 \\
\hline \multirow[t]{3}{*}{ オリエンタル } & $1 \prime$ & 7.0 & $9.2 \times 10^{9}$ & $1.9 \times 10^{9}$ & $2.3 \times 10^{8}$ & $8.5 \times 10^{5}$ & 100 & 0 \\
\hline & $7 \prime \prime$ & 7.0 & $2.3 \times 10^{9}$ & $3.3 \times 10^{9}$ & $1.3 \times 10^{9}$ & $2.0 \times 10^{5}$ & 39 & 0 \\
\hline & $8 \prime \prime$ & 7.0 & $2.9 \times 10^{9}$ & $4.6 \times 10^{9}$ & $2.1 \times 10^{9}$ & $9.0 \times 10^{4}$ & 46 & 0 \\
\hline \multicolumn{2}{|l|}{$\begin{array}{l}\text { グループ B } \\
\text { 実験開始時 }\end{array}$} & & $\infty$ & $7.5 \times 10^{8}$ & $7.5 \times 10^{8}$ & $8.8 \times 10^{5}$ & 100 & 0 \\
\hline \multirow[t]{2}{*}{$\mathrm{Px}$} & 4 日後 & 5.8 & $\infty$ & $2.2 \times 10^{10}$ & $4.0 \times 10^{10}$ & $6.4 \times 10^{5}$ & 100 & 0 \\
\hline & $5 \prime \prime$ & 5.8 & $1.7 \times 10^{10}$ & $5.0 \times 10^{10}$ & $5.0 \times 10^{10}$ & $4.5 \times 10^{4}$ & 100 & 0 \\
\hline \multirow[t]{2}{*}{$\mathrm{PF}$} & $6 \prime \prime$ & 5.0 & $1.0 \times 10^{11}$ & $3.1 \times 10^{10}$ & $3.6 \times 10^{10}$ & $5.5 \times 10^{6}$ & 100 & 0 \\
\hline & $7 \prime \prime$ & 4.4 & $3.4 \times 10^{10}$ & $9.9 \times 10^{9}$ & $1.2 \times 10^{10}$ & $1.0 \times 10^{3}$ 以下 & 100 & 0 \\
\hline \multirow[t]{4}{*}{ オリエンタル } & $6 \prime \prime$ & 7.0 & $1.1 \times 10^{10}$ & $2.8 \times 10^{9}$ & $2.2 \times 10^{9}$ & $9.1 \times 10^{5}$ & 79 & 0 \\
\hline & $7 \prime \prime$ & 6.6 & $5.7 \times 10^{10}$ & $2.2 \times 10^{10}$ & $1.4 \times 10^{10}$ & $2.1 \times 10^{8}$ & 64 & 1 \\
\hline & $13 \prime \prime$ & 7.0 & $1.1 \times 10^{9}$ & $1.2 \times 10^{10}$ & $7.4 \times 10^{9}$ & $1.0 \times 10^{6}$ & 61 & 0 \\
\hline & $14 \prime \prime$ & 7.0 & $7.9 \times 10^{9}$ & $1.0 \times 10^{8}$ & $7.1 \times 10^{8}$ & $1.0 \times 10^{6}$ & 71 & 0 \\
\hline \multicolumn{2}{|l|}{$\begin{array}{l}\text { グループ C } \\
\text { 害騟開始時 }\end{array}$} & & $\infty$ & $6.9 \times 10^{9}$ & $4.9 \times 10^{9}$ & $9.7 \times 10^{4}$ & 71 & 0 \\
\hline \multirow[t]{2}{*}{$\mathrm{PF}$} & 4 日後 & 5.0 & $\infty$ & $2.0 \times 10^{10}$ & $1.3 \times 10^{10}$ & $5.8 \times 10^{5}$ & 65 & 0 \\
\hline & $5 \prime \prime$ & 5.4 & $1.2 \times 10^{10}$ & $3.0 \times 10^{10}$ & $2.9 \times 10^{10}$ & $2.5 \times 10^{4}$ & 97 & 0 \\
\hline \multirow[t]{2}{*}{ オリエンタル } & $6 \prime \prime$ & 7.0 & $6.9 \times 10^{8}$ & $2.3 \times 10^{9}$ & $1.8 \times 10^{9}$ & $2.6 \times 10^{5}$ & 78 & 0 \\
\hline & $7 \prime \prime$ & 7.2 & $4.4 \times 10^{10}$ & $1.7 \times 10^{9}$ & $9.5 \times 10^{8}$ & $1.5 \times 10^{7}$ & 56 & 0 \\
\hline $\mathrm{Px}$ & $6 \prime \prime$ & 5.0 & $3.9 \times 10^{10}$ & $1.1 \times 10^{10}$ & $1.2 \times 10^{10}$ & $1.5 \times 10^{5}$ & 100 & 0 \\
\hline \multirow{3}{*}{ オリエンタル } & $1 \prime \prime$ & 7.2 & $3.9 \times 10^{10}$ & $1.6 \times 10^{10}$ & $1.4 \times 10^{10}$ & $2.0 \times 10^{7}$ & 88 & 0 \\
\hline & $7 \prime \prime$ & 6.4 & $5.0 \times 10^{9}$ & $6.0 \times 10^{8}$ & $5.5 \times 10^{8}$ & $3.5 \times 10^{6}$ & 92 & 0 \\
\hline & $8 \prime \prime$ & 7.0 & $2.7 \times 10^{10}$ & $7.9 \times 10^{8}$ & $7.7 \times 10^{8}$ & $4.0 \times 10^{6}$ & 97 & 0 \\
\hline
\end{tabular}

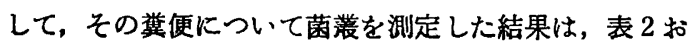
よび罒6に示した。

ネズミ鿓便中のリゾチーム含量は湘定しなかったので リゾチーム含量とビフィダス菌数との関係は不明であっ たが， A, B，C 群とも Px または PF を投与すると $\mathrm{pH}$ の低下,ビフィダス菌の增殖が認められた。とくに Px 投与でこの傾向が明らかであった。Px または PF 投与 を中止してオリエンタル固型飼料を投与すると，再び $\mathrm{pH}$ は上畀し、ビフィダス菌も減少した。ヒト天然栄盖 児の場合には腸内に㛔気性乳酸菌のビフィダス菌が王倒 的に多く，また筧便中にす多量のリゾチームが存在して いる。
要 約

リゾチームの生理効果を検討した。リジチームはカゼ インに対して in vitro では分解作用を示さない。

リゾチームを $130 \mathrm{mg} / 100 \mathrm{~g}$ 添加した有児用試験粉乳 を家鬼およびネズミに投与しつぎのような結果を得た。

1. 牛乳中には $0.03 \sim 0.17 \mathrm{mg} / 100 \mathrm{~g}$ ，人乳では $3 \sim 10$ $\mathrm{mg} / 100 \mathrm{~g}$ のソゾチームが含まれ，牛乳では人乳の約 $1 /$ 100 程度であった。

2. 家鬼にリゾチーム添加試験粉乳を投与した場合に は，血清および貸便中のリゾチーム含量が增加した。と くに梖便中に多い: 
3. 家鬼賞便中の $\mathrm{N}-$ 化合物の分布を Dowex-50Wィ オン交換樹脂で測定した結果，オリェンタル飼料と育児 用粉乳を投与した場合はその分布が異なり，育児用粉乳 投与によって粪便中には低分子 $\mathrm{N}-$ 化合物が多くなっ た。しかしリゾチーム添加試験粉乳と無添加粉乳との間 では明らかな差異は認められなかった。

4. リゾチーム添加育児用粉乳および無添加粉乳投与 によって，ネズミ鿓便中の $\mathrm{pH}$ は低下，ビフィダス菌は 增加した。とくに試験粉乳投与ではこの傾向が明らかで あった。さらに再びオリェンタル飼料を投与すると $\mathrm{pH}$ は上年し、ビフィダス菌す减少した。

\section{文献}

1) Abraham, P. E.: Nature, 140, 24 (1937)

2) Jolles, P. and Lauregui-Adell, J.: Atti. II, Symp. Intern. Lisozima, 1 (1961)

3) Chandan, R. C. and Shahani, M. K.: Nature, 204, 76 (1964)

4) Shahani, M. K. et al.: Intern. Dairy Cong., (1962), Sec. VIII, 1, 285

5) Meyer, K. et al.: J. Biol. Chem., 113, 479
(1936)

6 ) Salton, J. R. M. and Ghuysen, M. J.:Biochem. Biophy. Acta., 45, 355 (1960)

7) Mule, F.: Atti. I. Symp. Intern. Lisozima (1959)

8 ) Ferlazzo, A. and Lombardo, G.: Atti. II.Symp. Intern. Lisozima, 7 (1961)

9) Rossi, R.: Atti. II. Symp. Intern. Lisozima, 7 (1961)

10) Buccellato,G.: Atti. II. Symp. Intern. Lisozima, 7 (1961)

11) Poli, G. and Holeknecht, E.: Min. Pidiat., 3, 386 (1951)

12) Litwack, G.: Proceeding, Sociity of Experimental Biochemistry and Medicine, 89, 401(1955)

13）祐川, 西川, 末永: 雪印乳業技術研究所報告, No. 65 (1962)

14）祐川, 西川, 末永: 雪印乳業技術研究所報告, No. 67 (1963)

15) Jolles, P. and Jolles, J.: Nature, 192, 1187 (1961)

16) Smoleis, A. N. and Hartsell, S. E.: J. Bact., 58, 731 (1949)

（雪印乳業株式会社技術研究所）

ヒトの胎児の肝藏におけるフェニールアラニンからチロシンへの転換

ヒトの胎児 5 体（体重 $440 \sim 566 \mathrm{~g}$ ）について，死後 直らに次の処理を行なった。 $10 \mathrm{ml}$ のグルュース等張液 に溶かした $25 \mu \mathrm{C}$ の $\mathrm{DL}$ フンニールフラニン $-3-\mathrm{C}^{14}(0$. $05 \mathrm{mC} / \mathrm{mg}$ ) を，へその血管を通して肝藏に直接注入し さらに $5 \mathrm{ml}$ の等張液で血管内の放射性物質を肝缄へ洗 い込んだ。注入して 1 時間ののちに約 $1 \mathrm{~g}$ の肝臓を採取 し，ピクリン酸で脱たんぱくし，イオン交換樹脂カラム 法てアミノ酸を分析した。カラムからの溶出液の一部を 液体シンチレーションカウンターの $2 \mathrm{ml}$ flow cell に 流し, 各アミノ酸の放射能を調べたところ, Phe の他に
Tyrのピークにも放射能が計量され，その他のフミノ酸 では放射能は測定にかかってこなかった。Tyrの一部は さらに異化されたり，たんぱく質へ取り込まれたりする ため, Pheから Tyr 八転換した量は計算できなかった が, 以上の結果は, ヒトの肝臓で Phe から Tyr への 転換が行なわれていることをしめしている。（表 1 )

Phenylalanine Conversion to Tyrosine by the Human Fetal Liver.

by Ryan W.L., Orr W. : Arch.Biochem. Biophys., 113 (3), 684 686 (1966)

(堀井) 